\title{
Did Japan's high-growth success foster persistent stagnation?
}

\author{
W.R. Garside \\ Professorial Fellow, Research Institute, School of Political Science and Economics, Waseda University, Japan
}

This paper contends that there is a continuum in Japan's experience of growth and decline from the 1990 s to the turn of the century and beyond. A lingering attachment to the bureaucratic, financial and political underpinnings of high-growth success affected Japan's response to critical shifts in national and international economic circumstance once economic catch-up had been achieved. The institutional and ideational matrix constructed to deliver catch-up growth subsequently affected the content and fate of economic policy in subsequent decades. In the tensions that emerged between shifting circumstance and established practice can be traced the origins and nature of the boom and bust' years of the 1990s, the lacklustre reform programme that ensued and the reasons for continued stagnation into the new millennium.

Keywords: stagnation, banking crises, institutions, deflation, economic orthodoxy

JEL codes: $O 43, \mathrm{NOO}, \mathrm{E} 6 \mathrm{O}, \mathrm{H} 12$

\section{INTRODUCTION}

By the end of the 1980s, western observers were becoming increasingly sceptical of those distinctive features of Japanese capitalism that had hitherto been the scourge of neoclassi$\mathrm{cal}$ economic liberalism. During its high-growth years Japan had embraced a system of corporate governance that favoured employees more than shareholders and which saw firms more as communities than as private market 'owners'. Core employees of large and medium-sized firms enjoyed 'lifetime employment', seniority-linked wages, the imposition of firm-specific skills, and the predominance of 'enterprise unions' which embedded ruling corporate values. Banks rather than the capital market were the principal source of investment funds to the private sector, especially for riskier long-term ventures. The stability and adaptability of firms were enhanced further by the flow of information and other sources of support from powerful business groups linked by cross-shareholding arrangements. Businesses competed in final markets but within a system where the rules and the limits of such competition were directly influenced by the 'visible hand' of a state bureaucracy determined to foster national strength and security through international competitive advantage.

The collapse of the 'bubble economy' in the early 1990s and the ravages of the post1997 financial crisis throughout Asia led scholars, business-leaders and policymakers to criticize openly the institutions and practices that had featured so prominently in Japan's recent past. It appeared clear in retrospect that Japan's emerging troubles were not just those of policy error and economic mismanagement. The 'lost decade' of the 1990s revealed pervasive problems of institutional fatigue, social malaise and a loss of national purpose against a backdrop of radical changes in the external economic environment. 
By the end of the 1980s the high growth developmental system had become costly in terms of the inherent trade-offs involved and the resources required to sustain subsidies, tax cuts and technological upgrading. The country's domestic infrastructure and political system had by then become tied to a very different bipolar international order (Molteni 2001: 43-44).

The dramatic shift in the international environment during the early 1980s finally 'de-legitimized the working of the growth system, and ... helped accelerate the process of its aging' (Huang 2005: 188). Strains emerged from a variety of directions. Global capital flows and financial deregulation put pressure on Japan to adopt the trading and financial best-practice standards of the competitive West; rising personal incomes and demands for improved social welfare weakened the traditional stoic acceptance of 'rich Japan/poor Japanese'; and there were acknowledged difficulties in producing skilled labour for national upgrading whilst promotion of inward and outward investment pushed production networks beyond the national boundary, thereby weakening the national economic core.

The high-growth system moreover had produced a dysfunctional hybrid of superstrong exporting industries such as cars and machinery and super-weak domestic sectors such as food processing and textiles. Japan had 'a very thin social safety net, and so in order to protect jobs, weak domestic firms and industries were sheltered from competition by a host of regulations and collusion among companies. Ultimately, the system limited productivity and potential growth' (Katz 1998: 6).

Contingent conditions that had earlier enabled the Japanese economy to tolerate excessive competition based on over-lending, over-borrowing and a determination to expand market share began to weaken. The collapse of the fixed exchange-rate system and the free flow of capital across national borders during the 1980s shifted the emphasis away from the expansion of trade and production towards expansion of finance and monetary activity under a more liberalized order (Gao 2001: ch. 6). Large corporations were now able to source funding from outside the Japanese banking system, forcing the domestic banks to seek out softer and riskier customers to whom to lend in order to protect profit margins. The 'bubble economy' was in the making.

\section{FINANCIAL DISTRESS}

The complex interlocking array of institutions and of social and political accommodations that had epitomized the developmental state had created an inherent and powerful 'institutional logic' that stalled Japan's adjustment (La Croix/Kawaura 2006: 15-44). The operational potence of Japan's developmental state lay in its alleged capacity to anticipate change and to reorient policies accordingly. That proved ultimately to be Japan's weakness. Too many people had a stake in the established order. With a coalition of powerful political interest groups intent on retaining wealth and power and in the absence of a crisis sufficient to pose a major threat to growth and stability, many of Japan's ruling elites were able to muddle through the 1990 s accepting incremental but not fundamental reform (Garside 2012: 133-153). A close examination of Japan's political economy during the 1990s illustrates the point.

The interest-rate tightening introduced after the collapse of the equity market at the end of 1989 had a more draconian effect on the Japanese economy than merely curbing real-estate lending. The drastic decline in stock and real-estate prices weakened the health of banks and other financial institutions as the value of real-estate collateral eroded and the decline in the value of banks' equity holdings put pressure on bank capital. It was clear by 1992 that asset price deflation had led to deep falls in the value of bank capitalization and 
loan collateral and that the banking sector was riddled with huge stocks of non-performing loans.

Much of the blame for the deepening recession of the first half of the 1990s was directed at the Bank of Japan (BOJ). The generally accepted view is that, although the Bank systematically lowered interest rates in the aftermath of the bubble, it nonetheless kept the growth rate of base money extremely low, despite the mounting evidence of a decline in economic activity. Having allowed the money base to grow too much in the late 1980s its annual growth rate had doubled from 6 to 12 per cent during 1987-1989, driving the speculative mania and the creation of bad debts - the Bank let it fall to an annual growth rate of only 2 per cent during 1991-1993.

In the nervous climate of the times, Japanese banks became increasingly risk-averse, rationing credit and refusing to lend to borrowers thought likely to default. To make matters worse, banks were under pressure to meet new capital adequacy requirements that came into full effect in 1993. The Bank for International Settlements set equity (tier 1) capital at 4 per cent and the sum of tier 1 and tier 2 capital - the latter primarily subordinated debt at 8 per cent of a bank's risk-weighted assets. The effect was to circumscribe lending further, pushing marginal borrowers into bankruptcy, raising the levels of non-performing loans, and deepening the determination of the banks to restrict credit, especially to small and medium-sized firms. The continuous pressure exerted on banks' balance sheets by non-performing loans meant that bank lending continued to decline despite a loosening of monetary policy, putting downward pressure on private investment.

A combination of financial, institutional, and political pressures both contemporary and idiomorphic ensured that low interest rates, structural misalignments and a deepening problem of bad loans within the financial sector were able to coexist in a manner that frustrated the emergence of a more accommodating monetary stance. Despite repeated reductions of nominal short-term interest rates between 1992 and 1995 the economy languished, suggesting that the authorities had seriously underestimated the impact of deflationary forces.

Part of the problem was that the authorities were obliged to meet pressing and often rapidly changing economic and financial conditions without having considered whether their panoply of policy instruments, or more precisely policy priorities, needed to be altered. One problem arose from the deterioration in the formal main-bank/commercial-bank relationship of the high-growth years of the 1960s and 1970s. At that time the main bank had played an important role in allocating capital to productive investment and in facilitating industrial restructuring. As a large shareholder and often principal lender of a troubled company, the main bank would often initiate bail-out processes or restructure debt, acting to rescue (albeit with varying success) some of the country's largest companies and through them the reputation of the banking sector as an integral and trustworthy partner in the developmental agenda. Troubled firms in which a main bank had a large equity share were more likely than not during the pre-bubble period to downsize, incur lay-offs, and change their management structure, often enjoying better performance as a result.

However, as lending activity became riskier and less adequately monitored during the bubble years of the 1980s, the banks were less able to play the role of independent arbitrator than they had in the past, being both the source of and solution to the difficulties facing firms. Corporate restructuring became less of a priority and earlier main-bank-led corporate restructuring broke down, largely under the burden of non-performing loans. Moreover, the main-bank system itself came under stress. The main banks were reluctant to allow borrowers to default since that threatened the need to absorb some of the losses incurred by other creditors and because any default would reflect badly on their monitoring operations. In the face of regulatory weakness and the traditionally limited ability of 
shareholders to control bank activity, banks increasingly exercised forbearance, restructuring non-viable loans, extending loan maturity dates, increasing the ratio of unsecured loans as a percentage of total loans (a reversal of the trend in the late 1980s), and opening new credit lines to allow borrowers to repay overdue loans. Weak corporate governance enabled bank management to focus on market share rather than profitability, while the absence of adequate accountability reduced the incentive for banks to acknowledge the scale of the non-performing loan problem or to fashion policies to meet it. It was easier to await a revival in stock and property prices or a more general upturn in economic activity.

It was against this background that Japan became embroiled during the first half of the 1990 s in a misallocation of credit which in some respects proved as debilitating in its effect on productive investment as had the sudden switch from easy to tight and rationed credit. Large Japanese banks engaged in sham loan restructuring to keep credit flowing to otherwise insolvent borrowers (zombies) at the same time as they discouraged the entry of and investment by healthy firms, a situation exacerbated by the tradition of banks holding shares in some of their principal distressed borrowers, who in turn held bank shares. It is questionable, therefore, whether business investment slowed from 1991 to 1997 primarily because of a credit crunch.

The essential problem faced by the Japanese banking sector was that two complementary forces were at work; the one to rein in over-generous credit allocation that might through imprudence harm the capital bases of banks in general, the other to protect any further damage to the credibility and therefore financial stability of banks by shoring up those very firms whose bad loans had helped cause financial distress in the first place. 'Zombie congestion' exacerbated financial frictions by lowering collateral values, even for healthy firms (Caballero et al. 2008). All this stifled job creation, suppressed the incentive of inefficient firms to shed workers, and lowered industrial productivity, delaying the likelihood of rapid economic recovery.

Banks continued to extend credit to unworthy or at least financially suspect borrowers partly because of the institutional setting in which they were obliged to operate. The nature of bank regulation and supervision actually provided perverse incentives to provide additional loans to weak firms. Banks willingly rolled over loans to their existing distressed firms to avoid revealing to the public the scale of losses on their balance sheets. By allowing troubled borrowers to survive, the banks could avoid having to record the loans as realized losses.

Nor were the pressures ever entirely financial. There can be little doubt that political and administrative reaction to the troubled banking and corporate sectors during the first half of the 1990s served only to worsen the situation. Up until 1993 most regulators and politicians believed that Japan would soon resume its growth trajectory. The adjustment to asset prices was under way and corporations were promising to engage in cost-cutting reforms; fully fledged public action, it seemed, was not really required.

This left the financial sector particularly vulnerable. The adaptive institutional network responses of earlier decades were now found wanting in the face of the informational requirements necessary for effective financial regulation. They failed to produce any timely shift from relations-based regulation to rules-based regulation. The Liberal Democratic Party was heavily reliant upon the Ministry of Finance (MOF) for details of the state of the financial sector. But the information supplied by the Ministry proved tardy and incomplete so far as the fragility of financial institutions was concerned. The MOF was content to keep banks afloat, even with bad debts, if it avoided bankruptcies and lay-offs until such time as a recovery in economic activity and asset (especially land) prices occurred, especially as many non-performing loans were concentrated in the politically sensitive sectors of real estate, construction, retail, and service industries. The balance of interests between the banks, parliamentarians, bureaucrats and businessmen, in other words, favoured inaction. 
Full disclosure of the scale of non-performing assets and the health of individual banks threatened a severe collapse of public and overseas confidence in the sector as a whole. In the absence of adequate procedures to deal with a troubled financial sector save for the time-worn precept of burden sharing, the authorities, juggling simultaneously the imposition of greater regulation and supervision and the disposal of a huge volume of bad debt without invoking systemic crisis, simply bought time. Their actions stood in stark contrast to the Nordic countries, for example, which embraced transparency and swift remedial policy to curtail the impact of their own banking crisis in the 1990s. In Japan, however, there was hardly any pre-emptive action by government before 1997 to formulate a strategy for insolvent banks or to inject capital into weak banks (Garside 2012: 82-97).

To appreciate fully the balance of action and inaction on the part of the major financial agencies, it is necessary to consider briefly the political context in which financial policy was forged during the first half of the 1990s. The Liberal Democratic Party (LDP) briefly lost control of government in 1993 after almost 40 years of political supremacy. In the aftermath of high-profile financial scandals following the bursting of the bubble, Japan replaced its single non-transferable voting system with a mixed voting system that included proportional representation. Under the former scheme, between two and six parliamentary representatives had been elected from a single district. Many of them came from the ruling LDP party and therefore competed amongst themselves, waging candidate-centred campaigns rather than policy-centred ones. This mobilization of personal votes was time-consuming and costly but it enabled the LDP to garner sufficient representation to form single-party governments without coalition partners. The revised system from 1993 penalized smaller parties in favour of the large major political groupings with whom aspiring politicians wished to be associated. Although the LDP regained power in 1994 in coalition with the Social Democratic Party, politicians thereafter became increasingly embroiled in electoral and power concerns and intraparty conflict rather than in addressing the pressing economic and financial concerns before them.

Traumatized by its loss of political majority, the LDP sought desperately to preserve its influence and authority especially among the domestic interests it had long safeguarded, namely farmers, the construction industry, big business and small retailers. It swiftly distanced itself from the criticisms then being levelled against the MOF for regulatory incompetence and signalled the need for new forms of financial administration and regulation. As Johnson (2001: 76) puts it, the LDP 'no longer much cared about the LDP's chief domestic function: giving the economic bureaucracy enough autonomy for it to cultivate growth industries for the future ... [It] increasingly indulged in "bureaucratbashing" in an attempt to shift the blame for the recession'.

For its part, the MOF, threatened with a loss of power, became increasingly balkanized. Greater transparency and measured reform threatened to expose its paltry regulation of bank solvency and to deepen criticism of its operational efficiency. With a well-developed instinct for survival, it ruptured the flow of information, stalled regulatory reform and systematically disguised the full extent of the country's fragile financial condition for fear of being called to account for its failures in financial supervision. In the high growth period, it had been assumed that the Ministry would rescue failing financial institutions in order to protect national rather than strictly financial goals. Now it seemed that the same Ministry was more concerned with disguising past supervisory neglect.

It would have required a substantial degree of political coordination to have effected change in such an environment. The existing diffusion of responsibilities and the horizontal linkages between institutions made change in one area often dependent upon change in another, requiring political leaders to take bold initiatives in risky directions. That did not happen. 


\section{CONSTRAINTS ON POLICY}

In retrospect, what distinguished Japan in the 1990s was not the depth of recession per se (it did not reach the levels experienced by industrialized nations in the 1930s) so much as the duration of the downturn and the persistence of deflation and financial distress even at a time when interest rates came close to zero levels, a situation not witnessed elsewhere. Standard measures of price inflation (the GDP deflator, personal consumption expenditure, the consumer price index and the wholesale price index) all reflected increased deflationary pressure between 1992 and 1999, and especially from 1997, pointing to a deficiency in aggregate demand as the fundamental issue rather than inflationary supply-side problems or inadequate structural reform.

Nominal GDP in Japan (taken as a proxy for the growth of nominal aggregate demand) grew by less than 1 per cent a year in every year from 1992 to 1999 (except for 1996) and declined by nearly 3 percentage points in 1998. In the absence of aggressive measures to stimulate demand and with production capacity running far ahead of prevailing demand, monetary policy by the end of the 1990s had become severely circumscribed. Lower interest rates had failed to stimulate the economy because widespread excess capacity had made private investment insensitive to interest-rate changes; cutting taxes had not stimulated spending to any substantial extent because of workers' concerns about job security and future social service benefits. Sustained falls in prices had left real interest rates at relatively high levels, which worsened the burden of firms' debt and choked off consumers' desire to spend. There was a noticeable rise in precautionary saving after 1997, as fears about growth prospects, unemployment and fluctuations in income grew. In short, prolonged unanticipated deflation constrained monetary policy, hampered corporate profitability and raised the real burden of public and private debt, thereby weakening the impulses to recovery that monetary easing, fiscal spending, bank recapitalization and regulatory reform were designed to encourage. As deflation deepened, so did deflationary expectations. Japan had fallen into a process of almost self-sustained deflation.

\section{THE FATE OF FISCAL POLICY}

From a Keynesian perspective it seemed perverse that Japan did not embark upon a more sustained programme of fiscal expansion in order to overcome deficient aggregate demand and thereby strengthen the potential effectiveness of monetary policy. During the first half of the 1990s the Japanese authorities did introduce six fiscal-stimulus packages and combined them with tax cuts in late 1994. The overall fiscal balance shifted from a surplus of 1.5 per cent of GDP in 1991 to a deficit of almost 3.5 per cent in 1996. Nonetheless fiscal policy did not become entrenched as part of any coordinated policy to stimulate spending and growth.

Official claims of the scale of public investment spending during the 1990s were notoriously exaggerated; this is clear if allowance is made for the actual amounts of new spending that were undertaken. The effective tax cuts and public works components of the stimulus packages - the 'discretionary' elements of fiscal policy - were much smaller than the headline figure of overall spending (some ¥136 trillion between 1990 and 2000) might suggest. Stimulus packages frequently included large 'private investment incentives'; these were in effect loan programmes offered by institutions such as the Japan Development Bank to affect the allocation of funding among investment projects but they had little effect on the total level of investment undertaken. Similarly, many packages included elements of 'front-loading', which merely brought forward already planned spending on public works. The 'real water' content of the stimulus packages - 
that is, the proportion that had a direct effect upon activity - was quite small over the greater part of the 1990 s, often less than 50 per cent of the total. This suggests that a more aggressive fiscal policy might have moderated the recession even further, had the levels of new spending been greater than they actually were, given the predilection of both central government and local governments to spend less than headline figures suggested (Garside 2012: 114-116).

The comparison frequently drawn between the substantial public outlays undertaken in Japan during the 1990s and the meagre economic growth that the country registered rarely considers, however, what growth might have been in the absence of such spending. The real multiplier of fiscal spending lies in the difference in GDP in an economy already in recession before and after stimulus measures have been taken, and in the face of a massive drop in national wealth. It is arguable that monetary policy should have been used to prevent the Japanese economy from suffering prolonged recession; however, once the economy was faced with excess capacity, collapsed confidence and low interest rates, monetary policy had become reduced to, as Keynes would have it, 'pushing on a string'.

That the fiscal spending did not achieve more in Japan during the 1990s had less to do with its composition, wastefulness or misdirection than with the fact that it was not sustained for long enough. By 1996 economic recovery and inflation were anticipated; fiscal austerity was not, even given the fall in asset prices. Nonetheless, despite growth having risen to 3 per cent only a year before, government concerns over the rising budget deficit led it to commit a major policy error: a sharp reversal in fiscal policy in 1997. Controlling the growing deficit had by then become a policy priority. The share of taxes and social security contributions in national income (the 'national burden ratio') was rising in the face of an ageing population. Growing debt was seen as a threat to existing and future generations. The budget deficit of 4 per cent of GDP had unsettled the MOF which was desperate to restore some of its former reputation as the guardian of fiscal rectitude. Consumption taxes were raised from 3 per cent to 5 per cent in April 1997, the individual income tax cuts of the previous 2 years were terminated, and a 10 per cent rise in employees' health care co-payments was introduced. The combined effects eroded consumers' disposable income by an estimated 2.25 per cent in 1997 alone, denting overall spending.

Far from improving the deficit, the rise in taxes and the cuts in public expenditure during 1997 merely worsened it as continued economic contraction reduced tax revenue. The about-turn in fiscal spending was rapid and damaging. Total public works expenditure as a percentage of GDP - which had risen from 6.0 per cent in 1991 to 7.9 per cent in 1993 and had stood at 7.5 per cent in 1995 - fell to 6.4 per cent in 1997. The cumulative effect of the fiscal contraction persisted during the subsequent 2 years, reducing GDP growth by at least 2.5 per cent (Kuttner/Posen 2002: 550).

The weakening of the real economy during 1997-1998 briefly shifted the political consensus towards expansionary fiscal policy in order to stimulate domestic demand. The stimulus packages introduced in 1998 were expected to turn fiscal policy from somewhat contractionary to neutral. Although fiscal stimuli after 1995 had helped to neutralize the fall in corporate investment, to bolster aggregate demand and to generate some growth before fiscal consolidation reversed the process, the potentially positive effects of fiscal expansion in the later 1990s were muted by a growing mistrust of the likely success of government economic policy. Financing 'zombie' firms had helped perpetuate low productivity and stifle new investment. As growth stalled, the government continued to suffer a reduction in revenue, 'sticky' expenditure commitments almost ensuring that the fiscal situation would deteriorate. Macroeconomic conditions, including a tightening of monetary policy and rises in real interest rates and in the real exchange rate from 1998, dampened the influence of fiscal policy. Although there was a case for continued fiscal stimulus 
from 1997, there was still a fear that such outlays might be needed for an indefinite period, mainly because of the public's excess desire for savings beyond levels required for domestic investment. This structural savings surplus added a constraint that could plausibly have been solved by increased net investment abroad, but that ran the risk of courting unwelcome international reaction from countries fearful of Japan building up greater surpluses.

More fundamental was the fact that the gap between the country's actual and potential output had widened so much that even the revitalization of fiscal policy proved unable to sustain any sizeable recovery. Bald figures of the level of real gross domestic product did not adequately reflect the output losses generated by the protracted economic slowdown. Even when growth had slowed from the 1980s to the end of 1991, Japan registered an increase of nearly 3.8 per cent a year in real GDP. Between the end of 1991 and the end of 1999, however, the rate of growth of real GDP had fallen to less than 0.9 per cent a year. Had Japan grown by even 2.5 per cent a year, its real GDP in 1999 would have been almost 14 per cent higher than the level recorded (Garside 2012: 127).

Japan had been overwhelmed by three separate crises: the secular decline in long-term growth, partly as a result of technological catch-up and demographic slowdown; a banking crisis in the wake of the bursting of the asset bubble; and perverse macroeconomic policy which had reversed tax and fiscal policy at precisely the wrong time in 1997. Because Japan delayed getting its expansionary macroeconomic policy right, especially when it came to tackling deflation and low aggregate demand, it was never able to deal effectively with either its structural problems or the condition of its financial institutions.

\section{THE SHADOW OF THE 'LOST DECADE'}

At the turn of the century, many outside observers assumed that Japan would adopt radically different policies to regain at least some of its former economic prowess. Although the ensuing decade did witness spurts of growth and notable manufacturing export successes, the country failed to discover a path to sustainable high growth. One major stumbling block was the failure of the authorities to learn the lessons of the 1990s.

Until 2003 the Japanese economy performed disappointingly after the growth spurt at the turn of the century. By then the percentage growth rate of GDP had barely reached the level achieved in 1995. From 2003 to 2006 the average annual growth rate of real GDP in Japan (2.3 per cent) matched that achieved by the European Union during the same period and surpassed Japan's cyclical expansions of the late 1960s. Large (predominantly exporting) manufacturing firms were starting to embrace competition in the market place. They had rejected the postwar tradition of socializing risk and had embarked upon more market-oriented relationships with suppliers, banks and employees in order to become focused, innovative competitors (Schaede 2008).

Japan's economic recovery between 2004 and 2007 was underpinned by growth in exports, aided by a significant fall in the real value of the yen. For decades, however, Japan had neglected to address the fundamental problems of flagging demand and low productivity, especially in services and manufacturing for domestic consumption. Even when Japan's successful exporters had been earning substantial profits in the immediate past, increasing capital investment in cars, machine tools and electronics in particular, they had proved reluctant to expand wages. For many years, consumption had been supported by households running down their savings. The shrinking working-age population, the increasing reliance by corporations upon lower-paid contract workers, and the growing uncertainty among the ageing population about the future of public finances served thereafter to curb 
domestic demand and, with it, potential growth. Anaemic domestic consumption, however, meant that even moderate recovery remained heavily dependent upon export growth.

Japan's exposure to the substantial decline in export demand following the international financial crisis in 2007-2008 revealed how dependent the country was upon external developments over which it had little control. As the global financial crisis intensified, so did recourse to the yen as a 'safe' currency; this exposed the country to an asset-market driven currency appreciation that threw Japan's growth into reverse. Because Japanese interest rates had been considerably lower than those in the USA and elsewhere between 2002 and 2007, the yen remained weak as investors converted the currency into dollars. The weak exchange rate helped drive Japanese economic growth but the export price advantage was lost after 2007, once USA interest rates began to fall and the yen started to appreciate. Such appreciation undercut the price competitiveness of Japanese exports and eroded the yen value of profits made overseas.

What was needed more than currency intervention was a pro-growth, pro-competitiveness agenda. However, shifting employment patterns during the 1990s had embedded low wage growth in a two-tier labour market which disadvantaged the job and wage expectations of younger and especially female workers (Garside 2012: 154-167). Uncertainty had continued to stymie domestic demand during the 2000s, just as low tax revenue from poor growth strained the ever-rising national debt. That remained Japan's dilemma. Tax hikes remained unpopular and, as was demonstrated in 1997, were likely to prompt further decline at a time when domestic demand was already weak.

With the BOJ still convinced that deflation was the result of structural impediments rather than monetary policy, and with the MOF haunted by its earlier attempt to raise taxes before recovery was under way in 1997 , there was little prospect of the authorities deploying a unified monetary and fiscal policy to encourage sustainable growth.

During the high-growth period, the 'losers' in society had been compensated through public works and other forms of subsidized lending financed from growth revenues. Two decades of slow growth made it more difficult thereafter to sustain previous levels of compensation. Workers, consumers and households, aware of the dramatic shift in circumstance, remained suspicious of any radicalization policy that might weaken the underlying premises of the postwar social contract.

During the high-growth period, the trade-off between greater risk-taking, efficiency and stability had been relatively easy to accomplish because the risks were shared and their magnitude was lower than they subsequently became. If the authorities wished to challenge the idea that in the ensuing decades Japan would inevitably face low growth rates, fiscal denouement and the eclipse of a younger generation's aspirations, they would have to have domesticated their political and economic systems with what has been termed 'open, non-destructive conflict' incorporating behavioural, institutional and political changes 'extensive enough to constitute a second miracle' (Jones 2002: $130-131)$. Did the inauguration of 'Abenomics' herald such a putative transformation?

\section{IS 'ABENOMICS’ THE ANSWER TO JAPAN'S PERSISTENT STAGNATION?}

We have drawn sufficient attention to the critical elements of Japan's postwar political economy to establish a central premise of this paper, namely that the institutional and ideational matrix constructed to deliver catch-up growth affected the content, direction and fate of economic policy in the ensuing decades. Since we are concerned with the issue of continued stagnation, it is worth examining whether any aspects of Japan's past policy priorities are likely to hinder the path to sustained economic recovery by the policy 
mix encapsulated in 'Abenomics' (the term frequently used to describe the stimulus programme inaugurated by prime minister Shinzo Abe). This stratagem has three principal elements: a more activist monetary policy for the BOJ, a fiscal boost via increased spending on infrastructure in the medium term, and structural reform designed to raise longterm industrial productivity.

The BOJ's declared objective was to increase the rate of inflation to 2 per cent so that companies and individuals could take advantage of negative real interest rates. BOJ purchases of long-term government bonds were meant to depress their yield and so spur banks and companies to seek higher returns elsewhere, either by investing in the real economy or by investing abroad. Consumers were encouraged to revise their inflationary expectations: to spend now, partly because hoarded cash would lose value and partly because consumables would be higher in price at a later date. Such proactive spending was expected to boost industrial profits and further waves of consumer spending and corporate investment in a virtuous cycle of growth.

There are a number of fundamental problems with this orientation of policy, which mirrors the weaknesses of economic and financial policy in the troubled 1990s. It relies too heavily upon the effectiveness of monetary policy to be a driving force for sustainable growth; it is based on certain behavioural assumptions that are far from predictable; and it seriously neglects the role of demand.

One of the underlying presumptions of BOJ policy was that consumers would fear inflation more than they hated deflation and would be prompted to raise their consumption spending. But although luxury spending rose on the back of asset inflation during the early months of Japan's financial experiment, there was little evidence of a 'wealth effect' creating spillovers from the increased value of financial stocks and shares. Many Japanese were not the direct beneficiaries of stock-market gains. Retail figures revealed few signs of a massive peremptory spending spree.

Moreover the Bank's approach ignored the fact that people may not harbour the negative view of deflation that it presumes. Purist economists are always keen to point to the scourge of deflation: it damages financial assets, boosts debt service costs, undermines confidence and corporate profits, and lowers tax revenue. But to those who suffered the surge in living costs in the 1970s and who as part of a greying population favour falling prices over rising ones, deflation fast became a symptom of Japan's malaise - not its cause. Many players had already adapted to a deflationary perspective: households that had for years sustained living standards without the expectation of regular wage increases, companies that had engaged in cost-cutting rather than fighting for bigger market shares, and governments that had willingly amassed massive debt in order to avoid destabilizing reforms.

Fiscal initiatives have been pursued with some vigour under Abe's administration, entailing targeted spending with high multiplier spillover effects in infrastructure, in Fukushima especially but elsewhere too. It is not yet clear, however, whether the inbuilt prejudices against high fiscal spending borne of earlier decades have been substantially eradicated. From the early 1970s onwards, Japanese governments had organized extensive public works spending in rural areas and fiscal assistance to small businesses to garner political support. Critics were predisposed to condemn such flurries of fiscal activity as little more than the distributive arm of the LDP, encouraging the private sector to seek out 'easy money' from the government, where political advantage might be gained, rather than engage in riskier high technology ventures that might have stimulated new consumer and industrial demand. Although growth-inducing fiscal spending is a more prominent part of Abe's declared economic strategy than it was in earlier administrations, when it had to countenance resistance from the Ministry of Finance, it is still overshadowed by emphasis placed upon monetary policy as the catalyst of greater investment. The BOJ's 
imposition of negative interest rates on banks in early 2016, as an example, was deliberately designed to 'tax' financial institutions for keeping excess reserves at the BOJ which the Bank felt could be better used to lend to businesses and customers to promote investment and growth. It was also a marker of how risky it had been to place so much emphasis upon quantitative easing to reverse the deflationary mindset.

Slower exports (affected in part by hesitant growth elsewhere in the world, especially China) and weak domestic demand reflected the pervasive problem facing Japan: an inability to boost and sustain consumer spending, the driving force behind 60 per cent of Japan's economic activity. The difficulty Japan faces, however, in raising demand stems in part from labour market practices adopted by a corporate sector hard hit in earlier years by declining profits and asset values. Among those in the Japanese labour market most disadvantaged is the rapidly expanding underclass of temporary workers. Their contracts (when they can obtain work) are frequently stripped of the benefits enjoyed by their counterparts during the era of breakneck growth: jobs for life, incremental pay rises and seniority-based promotions. According to a Labour Ministry survey in 2014, a record high of one in six Japanese lived in relative poverty due to falling incomes in families with young children and the rise of poorly paid, irregular jobs. Many small and medium-sized enterprises and local economies are not reaping the benefits of massive monetary easing. Increases in the prices of food, gas and electricity hurt the domestic consumer. Such price rises are the cause of what meagre inflationary impulses are officially recorded (and hastily advertised), but they are not the result of strong consumer demand backed by wage increases. Nominal wages peaked in 1997 and have fallen on average thereafter due to restructuring and a marked shift in demand for cheap, irregularly employed labour. Businesses may have made increased profits from the monetary-induced yen depreciation during the early years of Abe's administration but the 'trickle-down' effect on consumer spending proved paltry.

For all the encouragement and at times admonitions delivered by Abe and the BOJ, Japanese corporations have been slow to improve substantially the prospects of younger and especially female workers wanting more permanent and highly paid jobs. The practices carried over from the 1990s of protecting older, permanent and more expensive workers at the expense of an increasingly large group of low-paid temporary employees explains why wages have not risen significantly, despite rising corporate profits, and why a broad revival of domestic demand remained elusive.

Demographics add a further dimension to worries about Japan's capacity to strengthen its global competitive position (Garside 2015: 58-65). Economists have calculated that the shrinking working-age population dragged down Japan's GDP growth by an average of just over 0.6 percentage points per year between 2000 and 2013 .

An ageing population focuses attention on the role of demand. Because young people on the whole tend to buy more durable goods (cars, appliances) while older ones direct expenditure more towards services such as medical care and travelling, aggregate demand during a demographic transition is often skewed toward the service sector relative to the manufacturing sector. Productivity in the non-manufacturing sector, however, has traditionally lagged behind that in manufacturing. Since Japan can ill afford any drag on its productivity performance it must seek out opportunities to stimulate demand even in the face of long-term shifts in the labour force.

Panel data of 20 OECD countries over the period 1960-1994 indicate, contrary to normal expectations, that fixed business investment (especially in inventories) has tended to rise in countries with an increased share of older people. Japanese people aged 60 years or older account for at least 40 per cent of Japanese consumption and their share is projected to increase further in the immediate term. The most obvious demand for medical and care services provides an opportunity for increased investment in such fields which, if 
more fully exploited, could contribute positively to the country's potential growth rate. In the decade or so since 2000, the population aged 65 or over increased 33 per cent in Japan and 16 per cent in the USA. However, spending on medical and nursing services during the same period increased by only 11 per cent in Japan compared to 74 per cent in the USA (Shirakawa 2012: 35).

Such data suggest a large potential opportunity for the private sector in Japan to invest significantly not only in the market for medical and nursing services but also in medical equipment and other health-related sectors. There are already developments afoot in high technology humanoid robotics to provide new advanced systems of care for the elderly as the size of the active workforce diminishes. There are beds that turn into wheelchairs, robots that respond to petting to help older people overcome the curse of loneliness, and intelligent toilets that have medical sensors to measure blood-sugar levels with data emailed to local GPs. The real challenge, however, is for Japan to promote greater venture capital to foster developments in biotechnology (only one example) and to encourage a greater flow of information and talent from outside Japan.

Hopeful developments such as these are, however, often fraught with countervailing pressures. The stimulus to demand and consumption that might be expected from dissaving by the elderly might well be offset by rising precautionary saving among the very same group if they become fearful that the size of public debt will diminish the government's commitment to social security pledges. In those circumstances, saving for one's own future could be regarded as a better option. And insofar as old-age dependency reduces the consumption of an already dwindling cohort of younger workers because of the increased tax and social security burdens imposed upon them, adults of childbearing age might reduce fertility further in an effort to sustain living standards, thereby exacerbating the fundamental longer-term problem. Having a more productive young labour force would help, but that begs the question of whether governments and firms have the educative/training programmes in place to effect such improvements.

Keynes's emphasis on sustaining domestic demand remains crucial to the argument. The approach has never been without its critics and they are virulent today, couching their arguments in terms of the negative effect of rising government debt upon economic growth. The Keynesian retort is that slow growth might be a cause of high debt rather than a symptom of it. There is no consensus among economists over the level of debt that harms growth.

The social, political and cultural complexities of Japan make it imperative that if the corporate sector is lackadaisical in providing stable and well-paid employment then the government must act to sustain demand, even in the face of immediate budgetary pressure. When Keynes called for a 'socialization of investment' in the late 1930s what he had in mind was not a command economy but rather the willingness of government to use its fiscal strength (which it alone possesses) to sustain investment and demand until such time as the private sector gains the confidence to invest for growth. That insight remains as relevant to Japan's economic dilemma as it was for Britain after the Great Depression.

Continued deregulation in Japan may eventually encourage companies to expand and to increase wages so that customers can spend more. But without efforts to sustain demand in the immediate term, the government faces the prospect of rising prices and a public that sees inflation more as the result of cost-push forces rather than demandpull and thereby threatening. Contrary to the hopes of the BOJ, shifts in consumer expectations may not put the economy on an inflationary track sufficient to boost corporate investment and growth.

A radical change in monetary policy through quantitative easing is not a sufficiently strong foundation in itself to foster sustainable growth. Reforms are needed to allow 
banks to lend more to innovate sectors likely to spur consumer demand, employers to hire younger people on stable and better-paid contracts, and for ventures judged likely to raise Japan's technological competitiveness (Murphy 2014). Abe's efforts to promote structural change have produced few tangible results to date, save vague promises to do more about employing older workers and improving the prospects of women in the market place. But structural reform is always easier to initiate in a growing economy rather than in a stagnant one. The administration's plans for structural reform, though not new, are laudable enough: to rid the country of anti-competitive practices, to encourage deregulation, to inaugurate tax reforms aimed at spurring industrial diversification and regional development, to lessen support to inefficient sectors, and to use freed-up resources to unleash entrepreneurial endeavour.

Structural reform, however, is a long-term strategy and requires advance action on other fronts. Apart from the changes needed in current employment practices - especially in encouraging the employment of older workers and females, and providing more income security for younger, creative workers - a country like Japan facing a debt-GDP ratio of some 230 per cent needs over time to reduce its structural fiscal deficit. But to do this the Japanese private sector needs in tandem to reduce its structural financial surpluses. In the longer term, the excess of retained earnings over investment must decline. Japan's private savings-almost entirely generated by the corporate sector - are too high in relation to plausible investment opportunities. Japan needs reforms that lower corporate savings, such as altered depreciation allowances, a tax on retained earnings and greater empowerment of shareholders.

Japan lacks the 'gasoline of demand' to spark its engine into action. The country requires a Keynesian approach to remedial policy if only to strengthen the potential effectiveness of monetary policy. Such a policy needs to work alongside a strategy of targeted high-multiplier fiscal spending to provide a foundation upon which structural reform can proceed, and a determination to encourage the private sector to be more proactive in raising wages as a spur to domestic spending. Such an agenda faced Japanese authorities decades ago but a combination of administrative, political, national and sectoral interests ensured that it was customarily ignored in favour of protecting bureaucratic elites and favoured industrial sectors. The extent to which such institutional inertia persists will determine the immediate fate of the Japanese economy.

\section{REFERENCES}

Caballero, R.J., Hoshi, T., Kashyap A.K. (2008): Zombie lending and depressed restructuring in Japan, in: American Economic Review, 98(5), 1943-1977.

Gao, B. (2001): Japan's Economic Dilemma: The Institutional Origins of Prosperity and Stagnation, Cambridge, UK: Cambridge University Press.

Garside, W.R. (2012): Japan's Great Stagnation: Forging Ahead, Falling Behind, Cheltenham, UK and Northampton, MA: Edward Elgar.

Garside, W.R. (2015): There may be trouble ahead: demography and Japan's economic prospects, in: Japanese Journal of European Studies, 3, 58-65.

Huang, X. (2005): The Rise and Fall of the East Asian Growth System, 1951-2000: Institutional Competitiveness and Rapid Economic Growth, London: Routledge Curzon.

Johnson, C. (2001): Japanese 'capitalism' revisited, in: Thesis Eleven, 66(1), 57-78.

Jones, E.L. (2002): The Record of Global Economic Development, Cheltenham, UK and Northampton, MA: Edward Elgar.

Katz, R. (1998): Japan: The System That Soured - The Rise and Fall of the Japanese Economic Miracle, Armonk, NY: M.E. Sharpe. 
Kuttner, K.N., Posen, A.S. (2002): Fiscal policy effectiveness in Japan, in: Journal of the Japanese and International Economies, 16(4), 536-558.

La Croix, S.J., Kawaura, A. (2006): Institutional change in Japan: theories, evidence and reflections, in: Blomstrom, M., La Croix, S.J. (eds), Institutional Change in Japan, London: Routledge, 15-44.

Molteni, C. (2001): Structural reforms in Japan: the attempt to transform the country's economic system, in: Weber, M. (ed.), Reforming Economic Systems in Asia: A Comparative Analysis of China, Japan, South Korea, Malaysia, and Thailand, Cheltenham, UK and Northampton, MA: Edward Elgar, 43-60.

Murphy, R.T. (2014): Japan and the Shackles of the Past, Oxford: Oxford University Press.

Schaede, U. (2008): Choose and Focus: Japanese Business Strategies for the 21st Century, Ithaca, NY: Cornell University Press.

Shirakawa, M. (2012): Demographic changes and macroeconomic performance: Japanese experiences, in: Monetary and Economic Studies, November, 19-38. 